\title{
気密ケース入り熱電変換モジュールの開発および廃熱利用への適用
}

\author{
神戸 満社, 地主 孝広的2, 石島 善三的2 \\ 的電力中央研究所, ₹ 201-8511 狛江市岩戸北 2-11-1. \\ 衴日立化成工業侏，广 270-2295 松戸市稳台 5-2-1 日立粉末治金侏)内
}

\section{Development of the Encapsulated Thermoelectric Modules and their Application to the Industrial Waste Heat}

\author{
Mitsuru Kambe ${ }^{\text {tr } 1}$, Takahiro Jinushi ${ }^{\text {하 } 2}$ and Zenzo Ishijima ${ }^{\text {하 } 2}$ \\ ฟ 1 Central Research Institute of Electric Power Industry (CRIEPI), 2-11-1 Iwado-kita, Komae 201-8511, Japan.

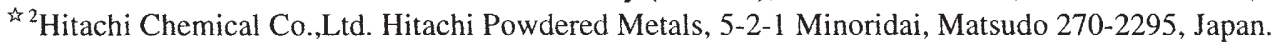

Received January 28, 2011

\section{SYNOPSIS}

An encapsulated thermoelectric (TE) module consists of a vacuum tight stainless steel container of $55 \times 50 \times 11$ $\mathrm{mm}$ in which a SiGe or BiTe TE module is encapsulated. This situation enables maximum performance and durability because (1) the thermal expansion mismatch between the hot and cold sides of the container can be accommodated by a sliding sheet in the container, (2) the TE module inside is always kept in a vacuum environment, therefore no oxidation can occur, and (3) the difference in pressure between the inside and outside of the container reduces thermal contact resistance inside the container. The encapsulated module could be applied to various environments and features maximum TE power with minimum installation cost. An attempt has been made to adopt the encapsulated TE modules to make use of waste heat of the powder metallurgy furnace. Heat transfer analysis and cost evaluation of the system have been made. Demonstration of the encapsulated TE module performance at the powder metallurgy furnace has been conducted and proven $3000 \mathrm{hr}$ operation.

\section{KEY WORDS}

Thermoelectric semiconductor, thermoelectric module, silicon germanium, bithmus telluride, industrial waste heat

\section{1 緒 言}

熱電変換とは, 半導体材料の両端に温度差を与えると両端 に電圧 (熱起電力) が生じる現象 (ゼーベック効果)を利用し て, 温度差を電力に変換する直接発電技術である，熱電変換 素子を用いた直接発電システムは, 構造が単純で可動部分が ないため高い信頼性が期待されるが, 出力密度およびエネル ギ一変換効率が低く，これまで宇宙用など特殊な用途で低い 出力規模に限られて開発が行われてきた.このうち米国の惑 星探査衛星に採用されたラジオアイソトープを熱源とする熱 電発電システムは約半世紀の使用実績があり, 高い信頼性は ボイジャー(1977年)およびガリレオ(1989 年)などで実証済 みである". しかし最近は地球温暖化抑止の観点から, 地上 での産業廃熱の有効利用への適用が期待されている.用途が 宇宙から地上に変わったことにともない新たな開発課題が提 起された.すなわち宇宙用の熱電変換モジュールは, 真空雾 囲気で使用され連続運転で温度変化がないため, 惑星探查衛
星用では10年以上の運転実績がある.これに対して地上の熱 電変換モジュール(以降モジュールと呼ぶ)は酸化䨌囲気や腐 食性の雾囲気中で使われることが多く, 熱源の起動・停止に ともなう熱サイクルを受けるため, 耐腐食性や熱応力緩和な どの対策が必要である.また宇宙用と地上用 (民生用) では, コストに対する要求は後者が格段に厳しい。

熱電変換モジュールの開発およびこれを用いた発電システ ムの開発には, 多くの開発項目が存在し, 多様な工学分野の 知見が必要である.

まず(1) 熱電半導体の開発である. 熱電半導体としては単結 晶体もあるが, 量産・低コスト化の観点では粉末冶金材料が 適すると考えられている. 発電性能(変換効率)の向上は, ドー パント ( $\mathrm{p}$ 型および $\mathrm{n}$ 型を作るためにドーピングする添加物) も含む材料成分系のみならず, その微細構造 (結晶粒度およ びその異方性の有無など)にも依存する ${ }^{2}$. 一方, 機械強度の 向上も重要である.これにより接合組み立て時および使用中 
の繰り返し熱応力に耐えられるモジュールが実現できる.す なわちこの開発では電子工学および機械工学 (材料工学, 粉 末治金工学)の知見が必要である.

次は(2) モジュール化技術である.熱電変換モジュールは $\mathrm{p}$ 型および $\mathrm{n}$ 型の熱電半導体に電極を接合し, 電気的に直列 に接続して構成する.ここで熱電半導体, 電極および接合材 には次の条件が要求される.まず熱電半導体と電極の線膨張 率は近いことが望ましい。これにより接合時と室温に冷却時 の熱膨張差に起因する熱応力を低減できる. 次に熱電変換モ ジュールの運転温度より接合材の融点が高いこと，かつ接合 材の融点より熱電半導体および電極の融点が高いことである. 以上の条件を満たす接合材を選定する必要があるが, 次に問 題となるのは接合材と熱電半導体・電極との拡散挙動である. 接合の可否のみならず, 接合界面に脆性の金属間化合物が生 成し亀裂の原因となることなどへの対策も必要である ${ }^{3-5}$. な お接合材を用いない拡散接合も検討された.これらには金相 学的な考察が必要である.

最後は(3) システム化技術である.モジュールの発電電力は, 熱電半導体に負荷される温度差のほぼ2 乗に比例するため, 出来るだけ大きな温度差を負荷する必要がある.しかし加熱 ダクトと冷却ダクトでモジュールを挟んで温度差を与えるシ ステムでは各ダクトとの接触界面に接触熱抵抗が存在するた め, 加熱・冷却ダクト間の温度差に比べてモジュール本体の 温度差は低減し，出力が大幅に低隇することになる．筆者ら の実験6によると，上記接触熱抵抗を低滅する工夫により，モ ジュール本体の温度差を 1.7 倍に増大でき, モジュール出力 は約 3 倍に向上することが確認されている. 上記の加圧力を 高めれば接触熱抵抗をある程度は低減できるが,これにより 脆弱なモジュールを破壊する恐れがある.このように良好な 熱伝導と熱応力緩和を両立することが課題である.これには 機械工学 (伝熱工学および材料力学) の知見を要する.

このように熱電変換モジュールの開発には多分野の知見が 必要である. 本論文ではこれらのうち特にモジュール化およ びシステム化の観点から，いかなる熱源にも適用可能な気密 ケース入りモジュールおよびこれを採用した廃熱発電システ ムの実証試験につき示す。

\section{2 熱電変換モジュール}

2.1 熱電半導体

熱電半導体の適用温度範囲は $200 \sim 1000^{\circ} \mathrm{C}$ 程度の範囲にお よび，低温用では BiTe，高温用では $\mathrm{SiGe}$ 系などが一般的で あるが, 性能向上およびコスト低減などの観点から新たな成

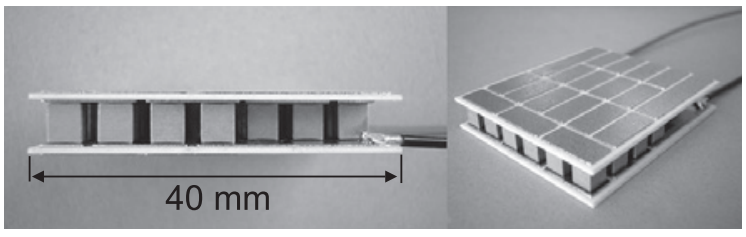

Fig.1 Conventional thermoelectric module.
分系の探索も行われている. 熱電変換素子のエネルギー変換 効率は, 温度領域および温度落差などに依存するが, 現状で は $10 \%$ 以下のものが一般的である.

日立化成工業(制では, 宇宙用なども視野に入れた最高温度 で使用可能なモジュールとしてSiGeモジュールを試作してい る. またさらに高性能化を目的に $\mathrm{SiGe}$ と $\mathrm{Mg}_{2} \mathrm{Si}$ を組み合わせ たモジュールの開発にも着手している.いずれも粉末冶金材 料を採用している. $\mathrm{Mg}_{2} \mathrm{Si}$ 核高性能かつ有害な物質を含まな い環境低負荷な熱電材料として期待されているが，高性能 $\mathrm{Mg}_{2} \mathrm{Si}$ はn型のみで, $\mathrm{p}$ 型は見出されていないのが現状である. このため $\mathrm{n}$ 型のみのユニレグ構造や他の $\mathrm{p}$ 型半導体と組合せ てモジュール化することが考えられている. 筆者らはSiGeモ ジュールの開発で培った製造技術をべースとして p 型を $\mathrm{SiGe}, \mathrm{n}$ 型を $\mathrm{Mg}_{2} \mathrm{Si}$ とした高温用 $\mathrm{SiGe} / \mathrm{Mg}_{2} \mathrm{Si}$ モジュールの開 発を進めている7.

2.2 両面スケルトン・モジュール6)

従来型のモジュール(Fig.1)は上下面にセラミックなどの基 板を備えるものが一般的である.このうち高温側の基板は熱 膨張するため, 基板上の電極とこれに接合される熱電半導体 との接合界面に熱応力が発生し, 熱サイクルの進行にともな い亀裂が入る恐れがある. 上記基板の熱膨張量は基板の大き さおよび温度変化幅に比例するため, 大型モジュールや高温 用モジュールほどその対策が重要である，従って従来型モ ジュールの平面寸法は通常は $4 \mathrm{~cm}$ 角程度で, 低温用で大きな ものでも $6 \mathrm{~cm}$ 角程度に制限されている.このような問題を避 けるため，高温側の基板を削除した「片面スケルトン・モ ジュール」がある.しかし宇宙用や自動車用などのモジュー ルでは, 低温側も室温より高い温度になる場合がある. 宇宙 用では低温側を水で冷やすことができないため，ラジエー ターパネルからの放射で冷却するシステムが一般的で, 例え ば高温側が $600 \sim 1000^{\circ} \mathrm{C}$ ，低温側が $300 \sim 500^{\circ} \mathrm{C}$ となる．ま た自動車用ではラジエーターの泠却水で冷却するため, 低温 側は $120^{\circ} \mathrm{C}$ を想定する必要がある. 各種熱源へのモジュール の使用温度条件をTable 1に示す.このような多方面への適用 を想定し，筆者らは電気絶縁板を全く備えない「両面スケル トン・モジュール」を開発した (Fig.2).この構造では, 電極 とこれに接合された一対の熱電半導体の熱膨張差のみが熱応 力の要因となるため, ほぼ完璧な熱応力緩和が可能となる. ただし本モジュールは単体では脆弱なため,これまでこのょ うな市販品は皆無である. 筆者らは取り扱い方法の自動化お よび治具の改良により，以下に述べる気密ケースへの封入を

Table 1 Heat source for thermoelectric modules

\begin{tabular}{|c|c|c|c|}
\hline $\begin{array}{c}\text { Heat } \\
\text { source }\end{array}$ & Industrial waste heat & Automobile & Space energy \\
\hline Hot side & $600^{\circ} \mathrm{C}$ & $\begin{array}{c}\text { Nominal: } 500^{\circ} \mathrm{C} \\
\text { Maximum: } 1000^{\circ} \mathrm{C}\end{array}$ & $600 \sim 1000^{\circ} \mathrm{C}$ \\
\hline $\begin{array}{c}\text { Cold side } \\
\text { (Coolant) }\end{array}$ & $\begin{array}{c}20^{\circ} \mathrm{C} \\
\text { (Water) }\end{array}$ & $\begin{array}{c}120^{\circ} \mathrm{C} \\
\text { (Engne coolant) }\end{array}$ & $\begin{array}{c}300 \sim 500^{\circ} \mathrm{C} \\
\text { (Radiator panel) }\end{array}$ \\
\hline & \multicolumn{3}{|c|}{ Even the module cold side becomes hot } \\
\hline
\end{tabular}




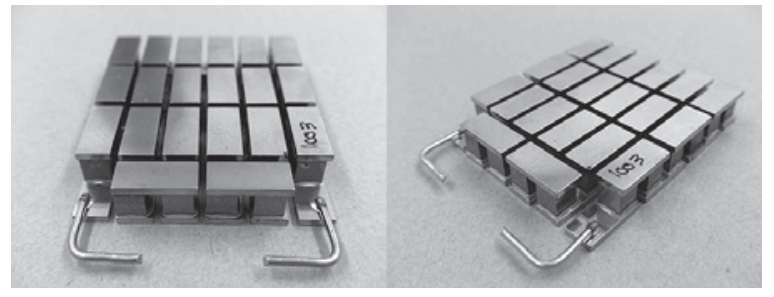

Fig.2 Both-sides-skeleton module.

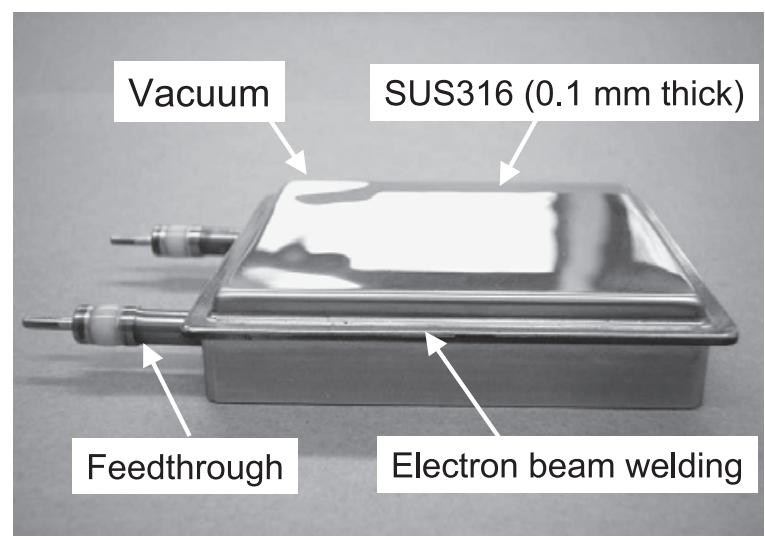

Fig.3 Encapsulated module.

可能にし,これによりユーザーの取り扱いやすさとモジュー ルの熱応力緩和 (長寿命化)の両立を達成した.

2.3 気密ケース入りモジュール6)

気密ケース入りモジュール(Fig.3)はステンレス製のケース $(55 \times 50 \times 11 \mathrm{~mm})$ にモジュールを封入したものである. 上面 のケースは厚さ $0.1 \mathrm{~mm}$ のステンレス製で内部が真空に保持さ れるため 1 bar $(0.1 \mathrm{MPa})$ で加圧され, 内部の各部材の接触熱 抵抗が低減される. モジュール本体は気密ケース内に真空に 保持されるため, 酸化䨌囲気や腐食性雾囲気などでも使用可 能である. 耐熱性気密電極がケースを貫通している. 気密 ケース入り SiGe モジュールの性能を Fig.4 に示す. 横軸は加 熱開始後の経過時間, 左縦軸は開放電圧, および回路抵抗を

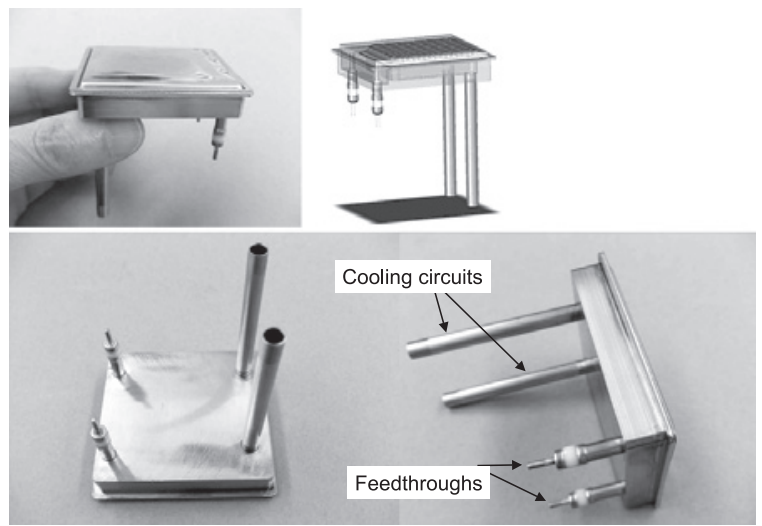

Fig.5 Encapsulated BiTe module with integrated cooler.

最適化した場合の電流と出力, 右縦軸は温度である。モ ジュール高温側 $550^{\circ} \mathrm{C}$, 低温側 $20^{\circ} \mathrm{C} に 6.5 \mathrm{~W}$ が得られる。

水冷パネルを内蔵した水冷パネル付きモジュール(Fig.5) は, 冷却ダクトの設置が不要で設置コスト削減が可能である. 特にモジュールを輻射で加熱する場合には, 熱源の近くに設 置して水冷配管を接続するだけで発電できる.

耐熱性気密電極および水冷配管は下向き (モジュール垂直 方向)および横向き(モジュール水平方向)を選択でき, 多様 な用途に適用可能である (Fig.6).

BiTeモジュールを気密ケースに封入する前後の性能比較を Fig.7および 8 に示す.

いずれも横軸は加熱開始後の経過時間, 左縦軸は開放電圧, および回路抵抗を最適化した場合の電流と出力, 右縦軸は温 度である. 気密ケース封入により出力が $16 \%$ ほど低下する. これは気密ケース内部の熱抵抗や側壁からの熱の短絡などが 原因である.モジュールの出力は熱電半導体の温度差の 2 乗 にほぼ比例するため, 気密ケース封入により熱電半導体の温 度差が約 $8 \%$ 低下したと推定される.このような出力の低下 を考慮しても, 気密ケース入りモジュールは次節に述べるよう なメリットがある.なおFig.9は以上に示した気密ケース入り

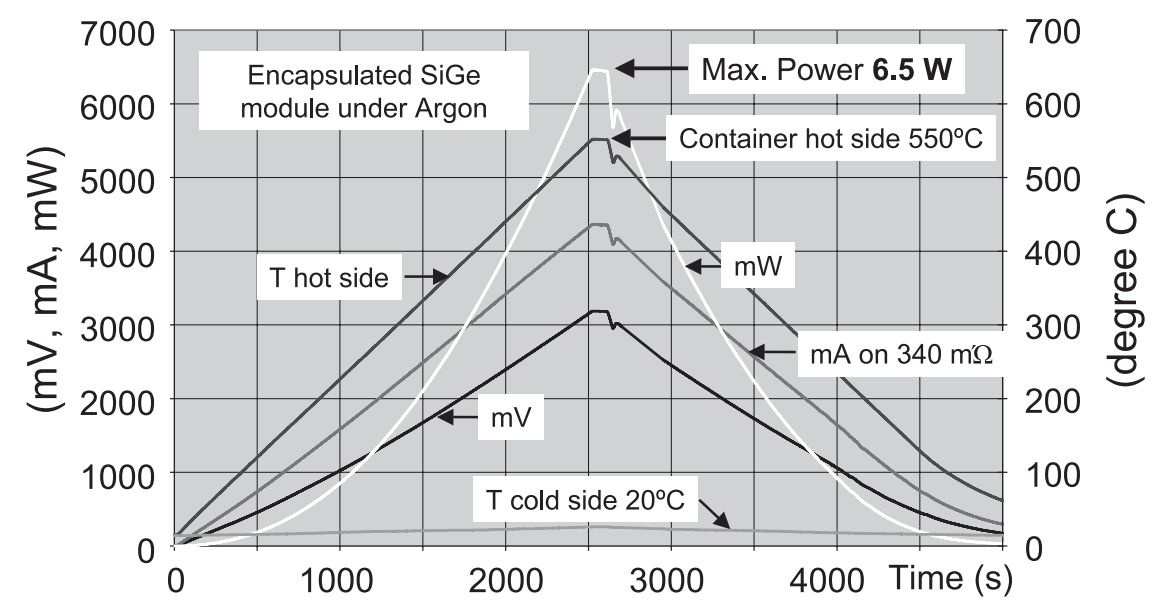

Fig.4 Encapsulated SiGe module performance. 


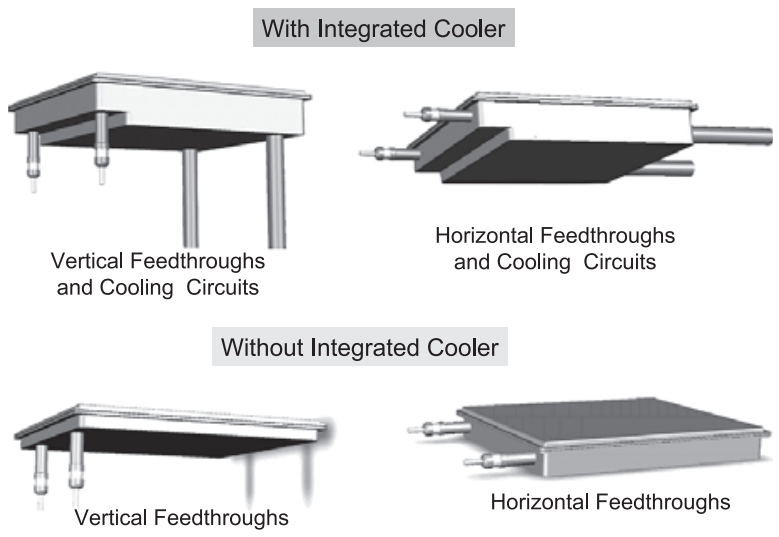

Fig.6 Various encapsulated modules.

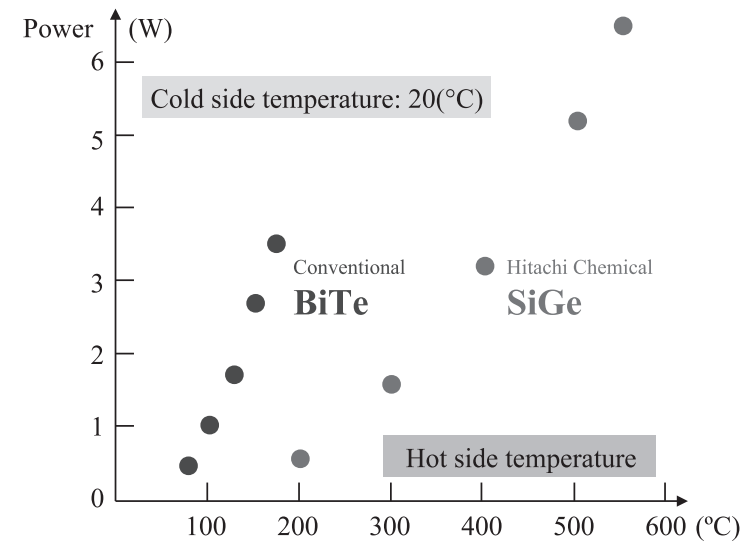

Fig.9 BiTe and SiGe module performance.

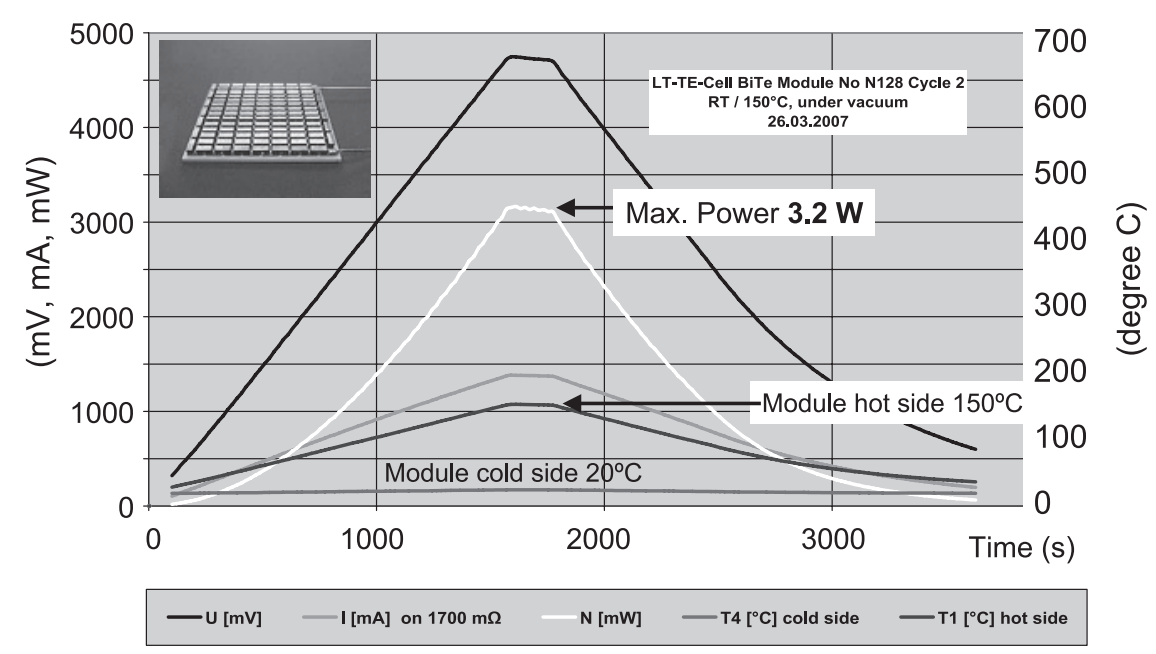

Fig.7 BiTe module performance (without container).

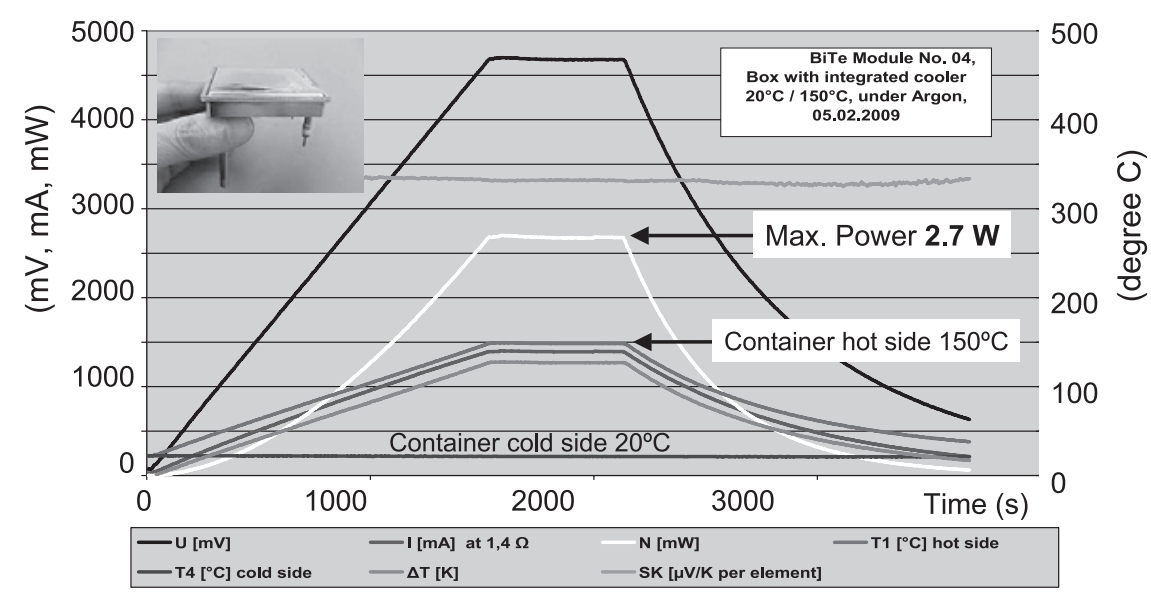

Fig.8 Encapsulated BiTe module performance.

のSiGeおよびBiTeモジュールの性能をまとめたものである. $200^{\circ} \mathrm{C}$ 以下ではBiTeモジュールの方が高い出力が得られ, か つ低コストである.よって排熱の温度に応じて両モジュール を使い分けることが性能とコストの観点で合理的である.
2.4 気密ケース入りモジュールによる設置自由度の拡大

気密ケース入りモジュールは多様な熱源への適用を可能に する. 設置例を Fig.10に示す. 加熱・冷却ダクト間で加圧する 方法 (Conduction coupling), 輻射熱で加熱する方法 (Radiation 
Applicable to various environments Conduction coupling / Radiation coupling / Convection coupling

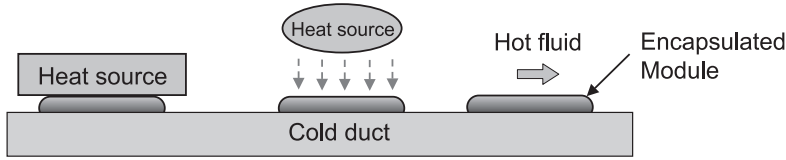

Fig.10 Application of the encapsulated modules to various environments.

coupling) およびガスや流体で加熱する方法 (Convection coupling) $)^{8)}$ な゙あらゆる設置方法が可能である.

加熱・冷却ダクト間で加圧する方法では, モジュールとダ クトの接触界面における接触熱抵抗を低減するために, 大き な加圧力が必要である.一方モジュールは加熱ダクトの運転 中と停止中の熱膨張変位量に追従する必要がある. 例えば オーステナイト系ステンレス製加熱ダクトの固定端から $1 \mathrm{~m}$

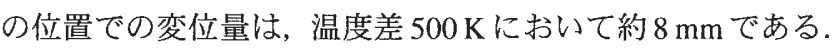
気密ケース入りモジュールはこのように両面から加圧されな がら一方がスライドする設置状況でも，モジュールを破壊す ることなく使用できる.

輻射熱で加熱する方法およびガスや流体で加熱する方法で は, 雾囲気に耐える材質の気密ケースによりモジュール本体 を保護できる. またモジュール加熱面以外への輻射を防止で きる. 水冷パネル付き気密ケース入りモジュールでは, 水冷 配管を接続して熱源の近くに設置するだけで発電できるため, 設備コストを格段に低減できる.

\section{3 廃熱利用熱電変換システムの実証試験}

3.1 粉末冶金燒結炉用熱電変換システムの伝熱設計およびコス 卜評価

粉末冶金焼結炉の構成をFig.11に示す.これは全長 10 数 $\mathrm{m}$ のトンネル状の炉で, 焼結品はコンベアーに乗せられて予熱 部, 均熱部および冷却部の順に移動する. 冷却部ではトンネ ル(炉心管)の外側に水冷ジャケットを備える. 冷却部に入る 際の焼結品の温度は $1100^{\circ} \mathrm{C}$ 程度で, この熱はトンネル壁を経 て水に伝達している. 冷却水は循環して再利用されているが, その熱は利用されずに捨てられている現状である.

この排熱を有効利用する $5 \mathrm{~kW}$ の発電システムを設計した. 発電システムの構成および伝熱解析結果をFig.11に示す. 熱 電発電にとって最も効果的なモジュール設置位置として, 冷 却部の上流部分 $2.5 \mathrm{~m}$ の区間を選定した.この区間のトンネ ル内壁に水冷パネル付き気密ケース入りモジュールを設置す る構成とした. モジュールは焼結品からの輻射熱で加熱され る. 焼結品はベルトに乗って下流へ移動するため，焼結品の 温度は冷却部入り口にて $1100^{\circ} \mathrm{C}$ 程度だが, 下流へ移動するに つれて次第に低下する。よって上流には高温用の $\mathrm{SiGe}$ モ ジュール，下流には低温用のBiTeモジュールを設置すること が, 性能とコストの観点で合理的である. SiGeモジュールの 高温側許容温度は $550^{\circ} \mathrm{C}$ のため, 上流部分のモジュールでは

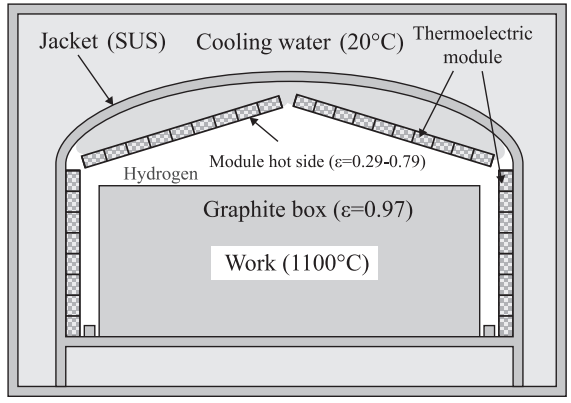

Cooling zone cross section

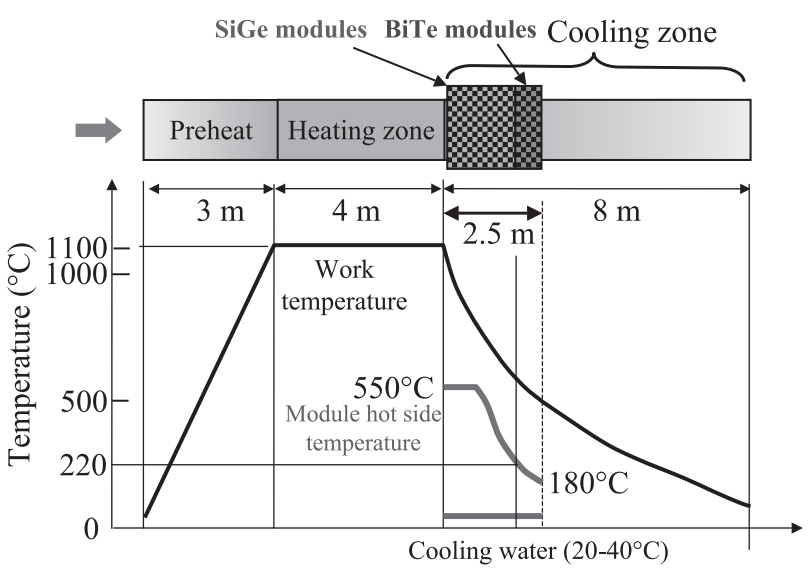

Fig.11 Powder metallurgy furnace equipped with thermoelectric system with result of heat transfer analysis.

この温度を超えないように, モジュール受熱面の輻射率を調 整している.モジュールを合計 1200 個設置することにより $5.6 \mathrm{~kW}$ (DC)の発電が出来るとの伝熱計算結果を得た. DC/AC 変換器の変換効率を 0.93 とすると $5.2 \mathrm{~kW}$ (AC) が得られるこ とになる. SiGeモジュールの出力はFig.4に示したように1個 あたり最大 $6.5 \mathrm{~W}$ だが, 最大出力を出せるのは最も上流のモ ジュールのみで, 下流のモジュールほど出力は低下する. モ ジュール 1 個当たりの平均出力は $4.7 \mathrm{~W}(=5600 \mathrm{~W} / 1200$ 個 $)$ で ある.

上記伝熱設計に基づきコスト評価を行った. 計算の前提条 件を以下に示す.

—焼結炉の稼偅率 : 0.92

- 業務用電力購入価格 (大口需要者向け): 14 円 $/ \mathrm{kWh}$

一熱電発電で得る電力は工場内で使用するものとし，その分 だけ電力会社から購入する電力 $(14$ 円 $/ \mathrm{kWh})$ を削減できる とする.

・冷却水のコストおよびこれを循睘するポンプの電カコスト は除外する. 熱電発電を行わない従来の焼結炉でもこれら は必要なためである。

・発電設備コストには, 熱電変換モジュールの他に据付工事 費, 設備維持費および付帯設備費(DC/AC変換器など) $)$ 含 む. 熱電変換モジュール本体のコストは全体の約半分程度 である. 
評価結果をTable 2に示す. 例えば発電設備コストが400円/ $\mathrm{W}(40$ 万円 $/ \mathrm{kW})$ ならば，コスト回収期間は 3.4 年である。な お現時点ではモジュールは試作段階のため, モジュール量産 価格については不明である。

なおドイッでは太陽光や風力発電など自然エネルギ一発電 の電力については $1 \mathrm{kWh}$ 当たり約 0.5 ユーロ(約 55 円)で買い 上げる制度があるが, 熱電発電はまだ含まれていない. わが 国でも熱電発電の電力買い上げ制度が整備されれば, 熱電発 電の急速な普及が見込まれる。

\section{2 粉末冶金焼結炉での実証試験}

水冷パネル付きBiTeモジュールを量産用のベルト式粉末冶 金焼結炉に設置し実証試験を行った。モジュール5個をパネ ルに配置して電気的に直列に接続し，また水冷配管も直列に

Table 2Cost evaluation of the thermoelectric system for a powder metallurgy furnace.

\begin{tabular}{|c|c|}
\hline $\begin{array}{c}\text { Plant cost } \\
\text { (includes thermoelectnc modules, installation, } \\
\text { mantenance and DC/AC converter) }\end{array}$ & $\begin{array}{c}\text { Investment recovery } \\
\text { period } \\
\text { (Year) }\end{array}$ \\
\hline$¥ 800 / W(=¥ 800,000 / \mathrm{kW})$ & 6.8 \\
$¥ 400 / \mathrm{W}(=¥ 400,000 / \mathrm{kW})$ & 3.4 \\
$¥ 200 / \mathrm{W}(=¥ 200,000 / \mathrm{kW})$ & 1.7 \\
\hline
\end{tabular}

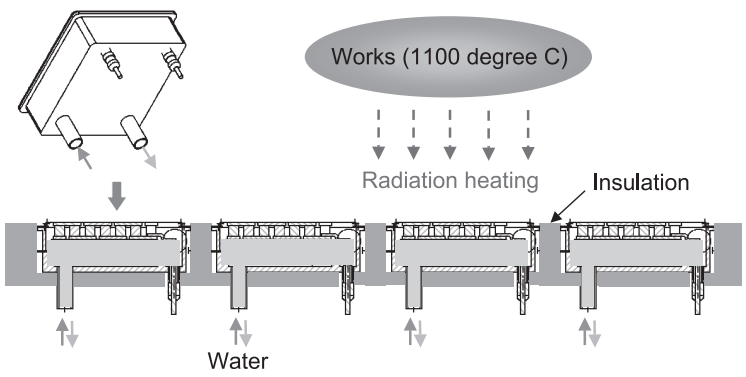

Fig.12 Schematic of the thermoelectric modules integrated in a panel.

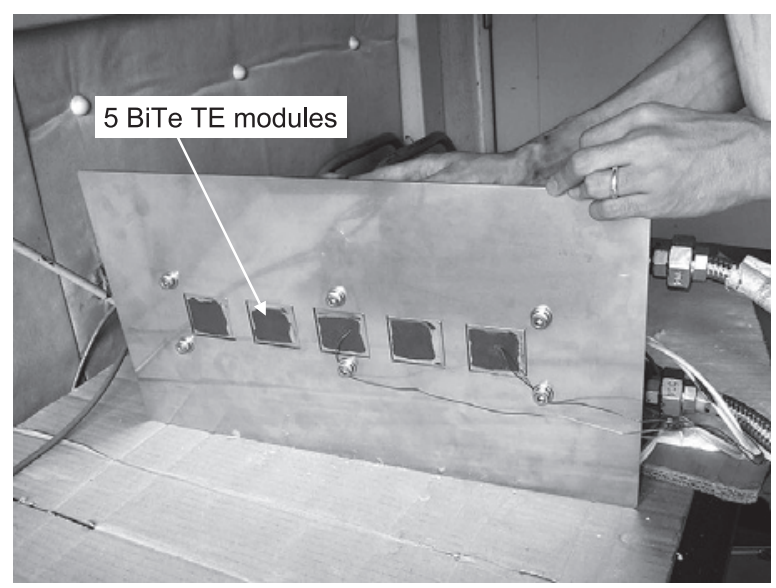

Fig.13 Thermoelectric modules integrated in a panel for demonstration test.
接続した (Fig.12および 13). モジュールの加熱面には輻射率 を高めるために耐熱性黒色塗料を塗布した。本焼結炉は生産 用に使用されているため, モジュ一ル設置のための十分な工 事期間が得られなかったため, 上記パネルは焼結炉出口に設 置した(Fig.14および 15). 焼結品はここではかなり冷却され ているが, 炉外からの空気の浸入を防ぐためのフレームカー テン(ブタンガスを常時燃焼)が設置されている. 従って焼結 品からの輻射によるモジュールの加熱は期待できないが，モ ジュールは上記フレームカーテンからの加熱を受ける. 数 ワットの発電試験を 3,000 時間実施したが，性能の劣化は見 られなかった。 今後はより高温の炉内冷却部に設置する予定 である、また日立化成工業の多様な排熱源に適用を試みる予 定である.

\section{4 まとめ}

熱電変換モジュールの開発およびこれを用いた発電システ 厶の開発には, 多くの開発項目が存在し, 熱電半導体の開発, モジュール化技術およびシステム化技術など, 多様な工学分 野の知見が必要であることを述べた. また以下を明らかにし た.

(1) 両面スケルトン・モジュールを気密ケースに封入する構 造により,ほぼ完璧なモジュールの熱応力緩和が可能と なる.またモジュールを多様な雾囲気に設置可能となる。

(2) 産業廃熱有効利用には $600^{\circ} \mathrm{C}$ 程度で使用可能なモジュー ルが必要だが，低温用モジュールとの併用が合理的であ る.

(3) 粉末冶金焼結炉の排熱を有効利用する熱電発電システム の伝熱設計を行い, 熱電発電の設備コストとコスト回収 期閒との関係を試算した。なお熱電発電の電力買い上げ 制度が整備されれば，熱電発電の急速な普及が見込まれ る.

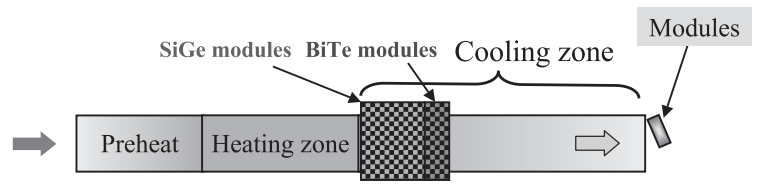

Fig.14 Thermoelectric modules placed at the furnace exit.

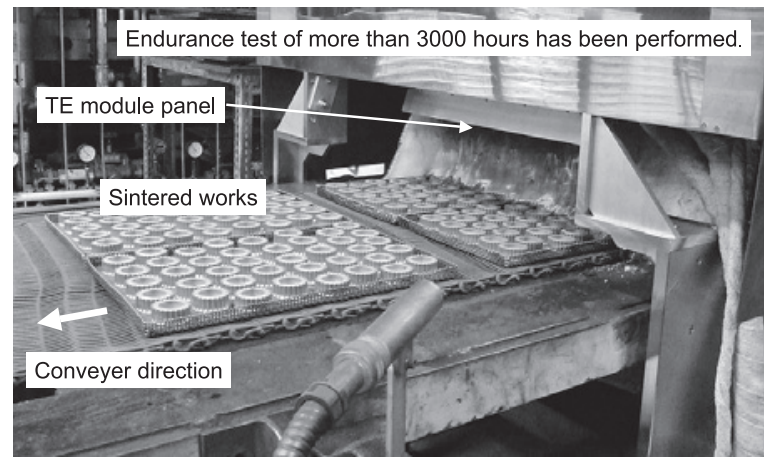

Fig.15 Demonstration test at the powder metallurgy furnace of Hitachi Chemical Co.,Ltd.. 
また今後の課題として，以下を検討中である.

（1）多様な用途への適用を狙って，気密ケース入りモジュー ルの種類を拡大する(水冷パネル付き, 電極および水冷配 管の向き, 超高温用など).

(2) 気密ケース入りモジュールのコスト低減方策についても 開発中である.同一の機能で安価な電子ビ一ム溶接およ びケース製法について検討中である.

\section{謝辞}

本研究開発は, (財)電力中央研究所と日立化成工業侏の共 同研究として実施した.

\section{文献}

1) J.A. Angelo: "Space Nuclear Power", Orbit Book Company, (1985).

2) J.P. Fleurial, et al.: "Progress in the Optimization of n-type and p-type SiGe Thermoelectric Materials", Proceedings of the Tenth Symposium on Space Nuclear Power and Propulsion, Albuquerque, NM, January, (1993).

3) J.A. Bond, et al.: "Development of a High Voltage Insulator Assembly for SP-100", Proceedings of the Seventh Symposium on Space Nuclear Power Systems, Albuquerque, NM, January,
(1990).

4) J.A. Bond, et al.: "Development of High Voltage Insulator, Compatible with Lithium at High Temperature for Use in the SP-100 Thermoelectric Cell", Proceedings of the Ninth Symposium on Space Nuclear Power Systems, Albuquerque, NM, January, (1992).

5) J.A. Bond, et al.: "Evolution of the SP-100 Conductively Coupled Thermoelectric Cell", Proceedings of the Tenth Symposium on Space Nuclear Power and Propulsion, Albuquerque, NM, January, (1993).

6) M. Kambe, T. Jinushi, and Z. Ishijima: "Encapsulated Thermoelectric Modules and Compliant Pads for Advanced Thermoelectric Systems", Proceedings for ICT/ECT2009, Freiburg, Germany, July, (2009).

7) T. Jinushi, Z. Ishijima, and M. Kambe: "Development of the SiGe/ $\mathrm{Mg}_{2} \mathrm{Si}$ Module", Abstracts of Autumn Meeting of Japan Society of Powder and Powder Metallurgy, (2010) 115.

8) M. Kambe, R. Morita, K. Omoto, Y. Koji, T. Yoshida, and K. Noishiki: "Thermoelectric Power Conversion System Combined with LNG Vaporizer", Journal of Power and Energy Systems (Japan Society of Mechanical Engineering), 2(2008) 13041319. 